\title{
PENGARUH MODEL SIKLUS BELAJAR 5E (Engagemant, Exploration, Explanation, Elaboration, Evaluation) TERHADAP KEMAMPUAN APLIKASI KONSEP SISWA PADA MATERI SISTEM SARAF
}

\author{
Andra Rian Mulyna, Tuti Kurniati, Tri Wahyu Agustina \\ Prodi Pendidikan Biologi, Program S1, Universitas Islam Negeri \\ Sunan Gunung Djati Bandung
}

\begin{abstract}
This research supported by the problems emerging in class xi mia sman 27 bandung because less increasing study results in learning biology students. To overcome these problems by using a learning process implemented learning model learning cycle5E. This study aimed to determine the effect of the Learning Cycle 5E model of application of the concept of students' abilities in the material of the nervous system as well as knowing keterlaksanaan process of learning by using learning model $5 \mathrm{E}$ learning cycle on the material of the nervous system.The method used is Quasi-Experimental Design with a sample that is class I and class XI XI MIA MIA II the number of students in each class of 30 students. The sampling technique used was purposive sampling. Research instrument used was a set of tests and observation sheet. Analysis of study data including normality test, homogeneity test and test hypotheses.Results of analysis keterlaksanaan learning process by using the learning cycle $5 \mathrm{E}$ model of the average values obtained $97.50 \%$ berkategorikan good enough for the activities of teachers and $96 \%$ berkategorikan good enough for the student activity. The results showed that the application of the concept of students' ability to use the learning cycle $5 \mathrm{E}$ learning model obtained an average value of 44.56 initial test, the final test of $72.17, \mathrm{~N}$ Gain of 0.50 berkategorikan being an indicator of high concept application that indicator application of the material that has been learned within the family, school, community. Application of the concept of students' abilities without using 5E learning cycle model obtained an average value of 43.31 initial test, the final test 55.26, N 0.21 Gain berkategorikan-low, high-concept application indicators are indicators of the application of the material that has been studied in the environment family, school, community. Hypothesis test results at the end of the test Learning Cycle 5E learning model on the nervous system material obtained t 5.06> 1.69 ttable at significance level of 5\%. Based on the results of this study concluded that there are significant learning model Learning Cycle 5E on the ability of the students expressed significant application of concepts and hypotheses accepted.
\end{abstract}

Kata Kunci: Application of concepts, Learning Cycle 5E.

\section{PENDAHULUAN}

Pendidikan adalah segala pengaruh yang diupayakan sekolah terhadap anak dan remaja yang diselenggarakan kepadanya agar mempunyai kemampuan yang sempurna dan kesadaran penuh terhadap hubungan-hubungan dan tugas sosial (Hidayat, 2010:29-30).
Kondisi pendidikan di Indonesia saat ini masih tertinggal dibandingkan dengan negara-negara maju lainnya hal ini sesuai dengan pendapat dari Sari (2012: 5) menyatakan bahwa, dunia pendidikan di Indonesia saat ini masih belum mampumengimbangi laju perkembangan 
saintek yang dinamikanya tidak lagi dihitung per hari.

Oleh karena itu Islam memandang bahwa pendidikanadalah suatu kewajiban yang harus dilaksanakan untuk menciptakan generasi yang agamis dan berwawasan luas sehingga derajat kehidupannya meningkat, sebagaimana tercantum dalam firman Allah Surat AlMujadalah ayat 11 :

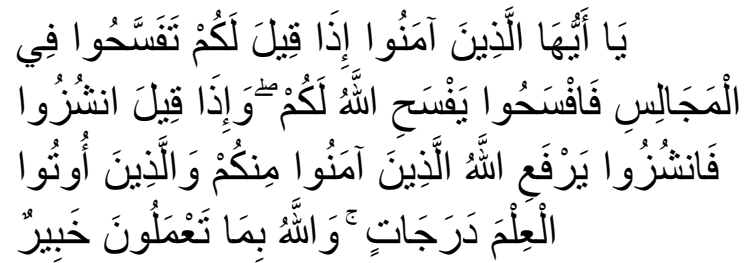

Artinya: "Hai orang-orang beriman apabila kamu dikatakan kepadamu: "Berlapang-lapanglah dalam majlis", Maka lapangkanlah niscaya Allah akan memberi kelapangan untukmu. dan apabila dikatakan: "Berdirilah kamu", Maka berdirilah, niscaya Allah akan meninggikan orang-orang yang beriman di antaramu dan orang-orang yang diberi ilmu pengetahuan beberapa derajat. dan Allah Maha mengetahui apa yang kamu kerjakan"

Ayat tersebut memuat suatu makna, di mana untuk mencapai keberhasilan dalam proses belajar mengajar khususnya pada penggunaan model pembelajaran memerlukan tahapan-tahapan yang sistematis dan terukur untuk mencapai tujuanpendidikan dalam meningkatkan kemampuan aplikasi sains dari hasil materi yang sudah dipelajari siswa.

Fungsi mata pelajaran Sains di sekolah, yaitu untuk menguasai konsep dan dapat mengaplikasikasikan konsep-konsep Sainsdalam kehidupan sehari-hari, oleh karena itu dibutuhkan pemilihan model pembelajaran yang cocok dan efektif untuk meningkatkankemampuan penguasaan aplikasi konsep Sains siswa.
Menurut Medriati, (2011:1) pembelajaran Sains di sekolah menengah belum memenuhi kualitas pembelajaran yang diharapkan sesuai dengan tuntutan kurikulum.Sebagai solusi dari permasalahan tersebut beberapa program dari pemerintah diselenggarakan untuk meningkatkan kualitas sains di dunia pendidikan sebagai contoh yaitu PISA (Programme Internationale for Student Assesment) yang merupakan suatu bentuk evaluasi kemampuan dan pengetahuan yang dirancang untuk siswa (Shiel, 2007). Program PISA tersebut didukung dengan kurikulum yang dimuat dalam UU. No. 20 Tahun 2003 ayat 1 yang berbunyi "Kurikum adalah seperangkat rencana dan pengaturan mengenai tujuan, isi, dan bahan pelajaran serta menjadi pedoman penyelenggaraan kegiatan pembelajaran untuk mencapai tujuan pendidikan tertentu".

Menurut Komalasari (2011:14) aplikasi konsep (applying) adalah proses pembelajaran yang menekankan pada penerapan fakta, konsep, prinsip, dan proseduryang dipelajari dalam situasi dan konteks lain yang berbeda sehingga bermanfaat bagi kehidupan siswa

Menurut Yunita (2012: 47) model siklus belajar merupakan strategi yang hebat bagi pengajaran sains di tingkat menengah pertama dan menengah atas karena model pembelajaran ini berjalan fleksibel dan menempatkan kebutuhan yang realistis pada guru dan siswa. Oleh karena itu model pembelajaran siklus belajar 5E ini sangat cocok untuk digunakan dalam materi sistem saraf,. karena model siklus belajar 5E ini merupakan salah satu modelpembelajaran dengan pendekatan kontruktivisme yaitu suatu pendekatan pembelajaran yang berpusat pada siswa (Wena, 2011:170).

Berdasarkan hasil wawancara terstruktur pada tanggal 15 Januari 2015 dengan guru mata pelajaran biologi kelas XI di SMAN 27 Bandung, bahwa 
kemampuan aplikasi konsep siswa kelas XI pada tahun sebelumnya untuk beberapa materi biologi tertentu kurang memuaskan. Salah satu materi yang dianggap susah dan kurang berhasil yaitu materi sistem saraf.

Kemampuan aplikasi konsep yang kurang memuaskan disebabkan karena proses pembelajaran di sekolah tersebut lebih berpusat pada guru, banyaknya siswa yang tidak memiliki buku paket kemudian tidak berusaha meminjam dari perpustakaan. Hal ini mengakibatkan potensi-potensi yang dimiliki siswa menjadi kurang berkembang, terutama dalam hal kemampuan aplikasi konsep.

Berdasarkan telaah pada silabus Kurikulum 2013 kelas XI SMA/MA semester genap, salah satu materi yang diajarkan pada semester ini yaitu sistem saraf, melalui materi tersebut, siswa dapat mengenal sel-sel saraf serta mampu mengetahui beberapa aktivitas kehidupan sehari-hari yang diatur oleh sistem saraf. Sehingga siswa akan mampu mengaplikasikan materi yang dipelajarinya dalam kehidupan sehari-hari. Menurut Champbell (2006: 754 ) sistem saraf merupakan salah satu sistem koordinasi yang bertugas menyampaikan rangsangan dari reseptor untuk dideteksi dan direspon oleh tubuh.

Pemilihan materi sistem saraf pada penelitian ini karena sistem saraf merupakan materi ajar yang diberikan di kelas XI semester II, selain itu materi sistem saraf cukup susah, kompleks dan rumit, serta materi sistem saraf ini merupakan materi yang sangat penting karena berhubungan dengan kesehatan dan gangguan-gangguan tubuh lainnya. Sehingga setelah diajarkan materi sistem saraf ini diharapkan siswa akan mampu mengaplikasikan konsep-konsep yang telah dipelajari meskipun dalam situasi dan kondisi yang berbeda.

Berdasarkan uraian di atas, maka akan dilakukan penelitian untuk mengetahui bagaimana kemampuan aplikasi konsep siswa pada materi sistem saraf.Untuk mengetahui hal tersebut, dilakukan penelitian dengan judul Pengaruh Model Pembelajaran Siklus Belajar 5E Terhadap Kemampuan Aplikasi Konsep Siswa Pada Materi Sistem Saraf.

\section{METODE}

Penelitian ini dilaksanakan dengan menggunakan metode penelitian kuantitatif untuk studi penelitian quasi eksperiment. Metode ini dilakukan karena pada kenyataannya peneliti mengalami kesulitan dalam menentukan kelas eksperimen dan kelas kontrol secara random. Kelompok eksperimen maupun kelompok kontrol tidak dipilih secara random (Sugiyono, 2012:114).

\section{HASIL DAN PEMBAHASAN}

Keterlaksanaan proses pembelajaran aktivitas guru dari pertemuan pertama sampai pertemuan kedua dengan menggunakan model pembelajaran siklus belajar 5Esebesar 97,50 dengan kategori cukup baik, sedangkan keterlaksanaan pada aktivtas siswa yaitu $96,00 \%$ dengan kategori cukup baik.

Berdasarkan tabel 3.5 dapat diketahui bahwa kelas yang menggunakan model pembelajaran siklus belajar 5E memperoleh nilai rata-rata tes akhir sebesar 72,17 dengan kategori baik.

Hasil analisis data penelitan dengan menggunakan model siklus belajar $5 \mathrm{E}$ menunjukan tes awal sebesar 44,6 dengan kategori sedang dan tes akhir 72,17 dengan kategori baik. $N$-Gain sebesar 0,50 dengan tafsiran kualifikasi sedang.

Hasil analisis data penelitan tanpa menggunakan model siklus belajar 5E menunjukan tes awal sebesar 43,1 dengan kategori rendahdan tes akhir 55,26 dengan kategori cukup. $N$-Gain sebesar 0,21 dengan tafsiran rendah.Nilai rata-rata indicator pembelajaran dengan 
menggunakan model siklus belajar 5E memperoleh rata-rata tesawal 45,82 dengan kategori kurang sekali, tesakhir 70, 59 dengan kategori cukup dan rata-rata $\mathrm{N}$ Gain 0,45 dengan tafsiran sedang.

Nilai rata-rata indicator pembelajaran tanpa menggunakan model siklus belajar 5E memperoleh rata-rata tesawal 41, 83 dengan kategori kurang sekali, tes akhir 55, 08 dengan kategori kurang dan rata-rata $N$-Gain 0,22 dengan tafsiran rendah.

Nilai rata-rata indicator aplikasi konsep dengan menggunakan model siklus belajar 5E dapat dilihat pada tabel 1 .

\begin{tabular}{clcc}
\hline No & \multicolumn{1}{c}{$\begin{array}{c}\text { Indikator } \\
\text { Aplikasi Konsep }\end{array}$} & $\begin{array}{c}\text { N-Gain } \\
\text { Rata- } \\
\text { rata }\end{array}$ & $\begin{array}{c}\text { Kualifik } \\
\text { asi }\end{array}$ \\
\hline & $\begin{array}{l}\text { Penerapan materi } \\
\text { yang telah } \\
\text { dipelajari dalam } \\
\text { lingkungan } \\
\text { keluarga,sekolah, } \\
\text { masyarakat } \\
\text { Penerapan materi } \\
\text { dalam } \\
\text { memecahkan } \\
\text { masalah }\end{array}$ & 0.49 & Sedang \\
& 0.40 & Sedang \\
\hline
\end{tabular}

Data tersebut dapat pula dilihat dalam bentuk diagram batang rata-rata indikator pembelajaran pada kelas yang menggunakan model siklus belajar 5E pada gambar 1.

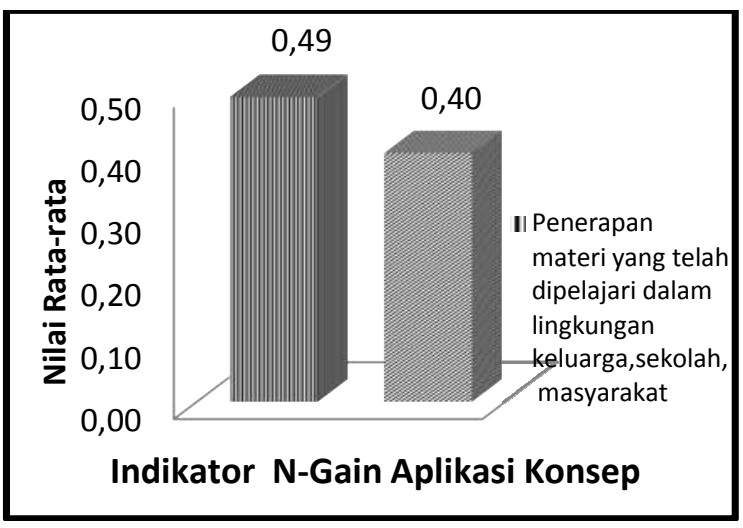

Gambar 1. Diagram Batang Rata-Rata Indikator $\mathrm{N}$-Gain Aplikasi KonsepSiswa Kelas yang Menggunakan Model PembelajaranSiklus Belajar 5E

Nilai rata-rata indicator aplikasi konsep tanpa menggunakan model siklus belajar 5E dapat dilihat pada tabel 2. berikut ini:

\begin{tabular}{clcc}
\hline No & \multicolumn{1}{c}{ Indikator } \\
Aplikasi Konsep & $\begin{array}{c}\text { Rata- } \\
\text { rata }\end{array}$ & Kualifikasi \\
\hline & $\begin{array}{l}\text { Penerapan materi } \\
\text { yang telah } \\
\text { dipelajari dalam } \\
\text { lingkungan } \\
\text { keluarga,sekolah, } \\
\text { masyarakat } \\
\text { Penerapan materi } \\
\text { dalam } \\
\text { memecahkan } \\
\text { masalah }\end{array}$ & 0.23 & Rendah \\
\hline & 0.22 & Rendah \\
\hline & & \\
\hline
\end{tabular}

Data tersebut dapat pula dilihat dalam bentuk diagram batang rata-rata indikator pembelajaran pada kelas yang menggunakan model siklus belajar 5E pada gambar 2.

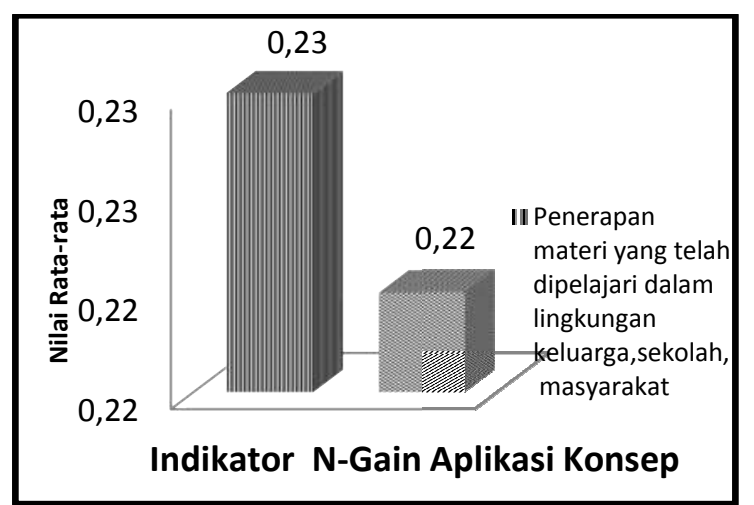

Gambar 1.2 Diagram Batang Rata-Rata Indikator Kemampuan AplikasiKonsep Siswa Kelas Tanpa Menggunakan Model Pembelajaran Siklus Belajar 5E

Hasil analisis keterlaksanaan proses pembelajaran dengan menggunakan model Siklus belajar 5E diperoleh nilai rata-rata 97,50\% berkategorikan cukup baik untuk 
aktivitas guru dan 96\% berkategorikan cukup baik untuk aktivitas siswa. Kemampuan aplikasi konsep siswa dengan menggunakan model siklus belajar 5E diperoleh rata-rata tes awal sebesar 44,56, tes akhir sebesar 72,17, N-Gain sebesar 0,50 berkategorikan sedang, indikator aplikasi konsep yang tinggi yaituindikatorpenerapan materi yang telah dipelajari dalam lingkungan keluarga, sekolah, masyarakat. Kemampuan aplikasi konsep siswa tanpa menggunakan model siklus belajar $5 \mathrm{E}$ diperoleh rata-tes awal 43,31, tes akhir 55,26, $N$-Gain 0,21 berkategorikan rendah, indikator aplikasi konsep yang tinggi yaituindikatorpenerapan materi yang telah dipelajari dalam lingkungan keluarga, sekolah, masyarakat. Hasil uji hipotesis pada tes akhir model pembelajaran Siklus Belajar 5E pada materi sistem saraf diperoleh thitung 5,06 $>$ ttabel 1,69 padataraf signifikansi 5\%. Dari hasilanalisis data yang dilakukan menunjukan bahwa penggunaan model siklus belajar 5E lebih signifikan dibandingkan dengan pembelajaran yang tidak menggunakan model siklus belajar $5 \mathrm{E}$ dan hipotesis diterima.

\section{KESIMPULAN}

Berdasarkan hasil penelitian mengenai pengaruh pembelajaran menggunakan model siklus belajar 5E terhadap kemampuan aplikasi konsep siswa pada materi sistem saraf dapat diambil kesimpulan sebagai berikut :

1. Keterlaksanaan proses pembelajaran pada kelas yang menggunakan model siklus belajar 5E pada aktivitas guru memiliki rata-rata sebesar 97,50\% dengan kategori cukup baik, sedangkan aktivitas siswa pada kelas yang menggunakan model siklus belajar $5 \mathrm{E}$ memiliki rata-rata sebesar $96.00 \%$ dengan kategori cukup baik.

2. Peningkatan kemampuan aplikasi konsep siswa dengan menggunakan model siklus belajar 5E menunjukkan bahwa indikator aplikasi konsep paling tinggi terdapat pada aspek penerapan materi yang telah dipelajari dalam lingkungan keluarga, sekolah, masyarakat yang memperoleh nilai rata-rata $N$-Gain sebesar 0.49 dengan kualifikasi sedang dan rata-rata $\mathrm{N}$-Gain dari kedua indikator sebesar 0.44 dengan kualifikasi sedang.

3. Peningkatan kemampuan aplikasi konsep siswa tanpa menggunakan model siklus belajar 5E menunjukkan bahwa indikator aplikasi konsep paling tinggi terdapat pada aspek penerapan materi yang telah dipelajari dalam lingkungan keluarga, sekolah, masyarakat yang memperoleh nilai rata-rata $N$-Gain sebesar 0.23 dengan kualifikasi rendah dan dan rata-rata $N$ Gain dari kedua indikator sebesar 0.22 dengan kualifikasi rendah.

4. Terdapat pengaruh penggunaan model siklus belajar 5E terhadap peningkatan kemampuan aplikasi konsep siswa pada sub materi pokok sistem saraf. Hal ini ditunjukkan dengan pengujian hipotesis tesakhir didapatkan nilai $t_{\text {hitung }}>t_{\text {tabel }}$ dengan nilai 5,06> 1,69 pada taraf signifikansi 5\%, dengan demikian hipotesis yang diajukan diterima. Perolehan nilai rata-rata tes akhir kemampuan aplikasi konsep siswa pada sub materi pokok sistem saraf dengan menggunakan model siklus belajar $5 \mathrm{E}$ lebih tinggi dibandingkan tanpa menggunakan model siklus belajar 5E masing-masing nilainya sebesar 70,46 dan 57,26.

\section{DAFTAR PUSTAKA}

Agustyaningrum, (2011). Implementasi Model Pembelajaran Learning Cycle 5E Untuk Meningkatkan Kemampuan Komunikasi Matematis Siswa Kelas IX B SMP Negeri 2 Sleman : Jurnal Jurusan 
Pendidikan Matematika FMIPA UNY, (34)

Arifin, Zaenal. (2010). Evaluasi Pembelajaran. Bandung: PT. Remaja Rosdakarya.

Arikunto, dkk. (2006). Penelitian Tindakan Kelas. Jakarta: Bumi Aksara.

Baharudin, Wahyuni, E.N. (2008). Teori Belajar dan Pembelajaran. Jogjakarta : Penerbit Ar Ruzz Media.

Campbell N.A. Mitchell LG, Reece JB, Taylor MR, Simon EJ.(2006) Biology, (5th ed). England: Benjamin Cummings Publishing Company.

Dahar, Ratna Wilis, (2010). Teori-teori Belajar. Jakarta: Erlangga.

Hake, R. (1998).Interactive-engagement versus traditional methods: A six thousand student survey of mechanics

tesdataforintruductoryphysics courses, American AssocIation of Physics Theachers. Vol. 66. No.1

Hardiyasa, Suma, Sadia. (2014). Pengaruh Model Siklus Belajar 5e Terhadap Keterampilan Berpikir Kreatif Dan Motivasi Berprestasi Siswa, eJournal Program Pascasarjana Universitas Pendidikan Ganesha Program Studi IPA, (4)

Herlanti, Yanti. (2006).Tanya JawabSeputarPenelitianPendidikan Sains. Jakarta: UIN SyarifHidayatullah.

Hidayat, A dan Machali, I. (2010). Pengelolaan Pendidikan. Bandung: Pustaka Educa.

Huda, M, (2014). Model-Model Pengajaran dan Pembelajaran. Yogyakarta: Pustaka Pelajar.

Isnaeni, W. (2006). Fisiologi Hewan. Yogyakarta: Kansius

Komalasari, K. (2011). Pembelajaran Kontekstual Konsep dan Aplikasi. Bandung: Refika Aditama.
Kurniati, T. (2015). Penerapan Model Siklus Belajar Untuk Meningkatkan Pemahaman Konsep Biologi Umum dan Kemampuan Aplikasi Sains Pada Perkuliahan Biologi umum. Tesis. Bandung: Prodi Pendidikan Biologi :Fakultas Tarbiyah UIN SDG Bandung.

Latifah.H. (2011): Biologi 2Universitas. Jakarta : PT RemajaRosdakarya.

Made, Ni Sri Mertasari,(2005). PeningkatanPenguasaanKonsepda nHasilBelajarMahasiswaPendidik anBiologidalam Mata KuliahKalkulusdenganPenerapanS trategiPembelajaranKontekstualm elaluiPendekatanPemecahanMasal ah.Jurnal IKIP Singaraja :PendidikanBiologi.

Purwanto, Ngalim. (2010). Prinsip-Prinsip dan Teknik Evaluasi Pengajaran. Bandung: PT Remaja Rosdakarya. (2012). Prinsip-Prinsip dan Teknik Evaluasi Pengajaran. Bandung: PT Remaja Rosdakarya.

Qarareh, Ahmed.(2012). The Effect of Using the Learning Cycle Method in Teaching Science on the Educational Achievement of the Sixth Graders.Journal off Education Science Faculty, Tafila Technical University, Jordan. (JurnalInternasional).

Quraish S, M. (2013). Tafsir Al Misbah. Jakarta: LenteraHati

Rusefendi. (2010). Dasar-dasar penelitian pendidikan. Bandung: Tarsito.

Roestiyah, D, (2008). Strategi Belajar Mengajar. Jakarta: Rineka Cipta.

Sanjaya, Wina, (2006). Strategi Pembelajaran Berorientasi Standar Proses Pendidikan. Jakarta : Prenada Media Group

Slameto. (1999). Evaluasi Pendidikan. Jakarta: PT Rineka Cipta. 
Slavin, Robert E. (2011). Psikologi Pendidikan Teori dan Praktik. Jakarta : PT Indeks

Suherman, Eman dkk. (2009). Strategi Pembelajaran Matematika Kontemporer. Bandung: UPI

Suripto, (2006). Struktur Hewan. Bandung: ITB

Subana. 2005. Statistika Pendidikan. Banndung: Pustaka Setia.

Sugiyono. (2010). Statistik Untuk Penelitian. Bandung: Alfabeta.

Surapranata, Sumarna. (2009). Analisis, Validitas,

ReliabilitasdanInterpretasiHasilTe s.ImplementasiKurikulum 2004. Bandung: PT. RemajaRosdaKarya.

Trianto, (2009). Mendesain Model Pembelajaran Inovatif-Progresif. Jakarta: Prenada Media Group

Warsono, Prof. Dr, Ms, dkk.(2012). Pembelajran Aktif Teori dan Asesmen. Bandung: PT Remaja Rosdakarya.

Wena, M. (2011). Strategi Pembelajaran Inovatif Kontemporer. Jakarta: Bumi Aksara.

Wibowo, M. Waslaluddin. Penerapan Model Pembelajaran Siklus Belajar (Learning Cycle5E) Dalam Meningkatkan Hasil Belajar Siswa Pada Matapelajaran Teknologi Informasi dan Komunikasi. Pendidikan Ilmu KomputerFPMIPA UPI.

Windayana, (2007). Pendidikan Matematika I. Bandung: UPI Kampus Cibiru

Yunita.2012. Model-Model Pembelajaran Kimia. Bandung: Cv Insan Mandiri. 